\title{
Identifying the configurational paths to innovation in SMEs: A fuzzy-
}

\section{set qualitative comparative analysis}

\author{
Meysam Poorkavoos \\ Roffey Park Institute, Horsham, West Sussex, RH12 4TB \\ Meysam.Poorkavoos@roffeypark.com
}

\section{Yanqing Duan}

Business School, University of Bedfordshire, Luton, LU1 3JU

Yanqing.duan@beds.ac.uk

John S. Edwards

Aston Business School, Aston University, Birmingham, B4 7ET

j.s.edwards@aston.ac.uk

Ramakrishnan Ramanathan

Business School, University of Bedfordshire, Luton, LU1 3JU

$\underline{\text { Ram.Ramanathan@beds.ac.uk }}$ 


\begin{abstract}
Using fuzzy-set qualitative comparative analysis (fsQCA), this study investigates the conditions leading to a higher level of innovation. More specifically, the study explores the impact of inter-organisational knowledge transfer networks and organisations' internal capabilities on different types of innovation in Small to Medium size Enterprises (SMEs) in the high-tech sector. A survey instrument was used to collect data from a sample of UK SMEs. The findings show that although individual factors are important, there is no need for a company to perform well in all the areas. The fsQCA, which enables the examination of the impacts of different combinations of factors, reveals that there are a number of paths to achieve better incremental and radical innovation performance. Companies need to choose the one that is closest to their abilities and fits best with their resources.
\end{abstract}

Keywords: Innovation, innovation management, Inter-firm Networks, Knowledge Transfer, fsQCA 


\section{Introduction:}

With increasing global competition in the current business environment, it is vital for companies to look for strategies that provide them with sustainable competitive advantage. The abilities to innovate and to manage inter-organisational relationships are two widely recognized critical factors for business success. Although prior studies have attempted to examine inter-firm networks and their effects on innovation (e.g. Abernathy \& Clark, 1985; Ahuja, 2000; Moller, Partanen, Rajala, \& Westerlund, 2007; Powell, Koput, \& Smith-Doerr, 1996; Rodan \& Galunic, 2004), a number of gaps can be identified.

First, most research has studied network effects on overall innovation performance. Only a few articles (De Propris, 2002; Gilsing, Nooteboom, Vanhaverbeke, Duysters, \& van den Oord, 2008) have considered the effects of inter-firm networks on different types of innovation. Moreover, the majority of studies on the degree of novelty of innovation have focused on large firms (Amara, Landry, Becheikh, \& Ouimet, 2008) ignoring the fact that small firms are not simply smaller versions of larger organisations (Moller et al., 2007).

Second, Meeus and Faber (2006) argue that researchers have never used real network features as indicators. For example, patent citation does not necessarily reflect network interaction: they can be interaction independent (Meeus \& Faber, 2006). Another example is the use of alliances which usually has been measured by announcements made by the firm. However, typically there is no attempt to validate if all these alliances have been actually implemented. Companies, in order to be innovative, need to access different types of resources (e.g. funds and knowledge). SMEs, because of their limited resources, do not have access to all the necessary resources that they require for innovation. Establishing relations with other companies and exchanging resources with partners is one of the ways that can help them to address this issue. Many studies have investigated and 
confirmed the positive impact of networking with other companies on innovation performance (e.g. Ahuja, 2000; Ahuja \& Katila, 2001; Boschma \& Wal, 2007; De Propris, 2002).

Third, it is also argued that companies without internal capabilities for innovation will not be able to benefit from their superior network position (Zaheer \& Bell, 2005). SMEs, in order to be innovative and increase the novelty of innovation, must improve their learning capabilities (Amara et al., 2008). Learning capabilities refers to their ability to generate new knowledge internally as well as exploiting resources that are available outside the firm (e.g. clients, suppliers, universities). Other researchers also confirmed the importance of internal capabilities (Hakansson, 1989; Hippel, 1988) together with networking and knowledge exchange between partners on the innovative performance of companies. Therefore, to study innovation in SMEs, it is vital to consider both internal factors and external influences. Adopting a social network perspective will help to better understand the effect of the external influences. To address the firm's internal capabilities for innovation creation, innovation management practices adopted by the firm should also be studied. From a resource based view of the firm (RBV), innovation strategy, human resource management and creativity/idea management reflect valuable and inimitable internal capabilities and play an important role in innovation performance. However, no previous studies appear to include these as internal factors.

Fourth, most innovation studies have employed conventional statistical methods (e.g. regression and structural equation modelling) to test causality, but Woodside (2013) argues that they are often less proficient at handling multi-faceted interdependencies between variables because they are typically based upon linear and symmetric relationships between variables of interest. A new analytic approach, fuzzy-set qualitative comparative analysis (fsQCA), has gained increasing attention and application in recent years. This is an approach to exploring complex complementarities between various factors communally influencing an outcome of interest (Cheng, Chang, \& Li, 2013; Fiss, 2011; Leischnig, Geigenmueller, \& Lohmann, 2014; Ragin, 2008; 
Woodside, 2013). It enables researchers to identify configurations of causal conditions that contribute to an outcome and to detect equifinal solutions, that is alternative pathways or combinations of causal conditions for an outcome to occur (Ragin, 2008). However, only a few studies have used fsQCA in innovation research (e.g. Cheng et al., 2013; Ganter \& Hecker, 2014; Stanko \& Olleros, 2013). Ganter and Hecker (2014) explore the causal interrelationships between antecedents of organisational innovation (e.g. firm size, education, knowledge source, competition, technology change, products characters, etc.); Stanko and Olleros (2013) investigate knowledge spillover mechanisms' effects on industry innovativeness and profit using fsQCA to identify specific configurations of these mechanisms associated with the outcome; Cheng et al. (2013) develop an integrated framework examining antecedent paths including organization-related, project-related, process-related, product-related, and market-related categories to successful product innovation. However, none of them distinguish between radical and incremental innovation, thus their studies are unable to shed light on how inter-firm network characteristics and innovation management capabilities contribute to the two types of innovation. Ganter and Hecker (2014) call for more applications of fsQCA to the field of innovation study because it "holds great promise of advancing the knowledge of several issues ranking high on the agenda of current innovation research” (p. 1291).

To address these research gaps and thus advance our understanding of inter-firm relationships and innovation performance, this research aims to examine the impact of inter-organisational knowledge transfer networks and organisations' internal capabilities on different types of innovation in SMEs. From the resource based view of the firm, the study draws together RBV theory and network theory to examine the influences of the external resources via knowledge transfer networks and the firm's internal capabilities of innovation management on the types of innovation. Using a new approach of fuzzy-set qualitative comparative analysis, the research is able 
to provide a fresh insight into the different configurational paths to successful innovation in hightech SMEs.

\section{Theoretical considerations}

This study focuses on innovation, thus this section reviews the innovation literature and discusses the theoretical considerations of the study.

\subsection{Radical and Incremental Innovation}

Innovation is a heterogeneous phenomenon and so a distinction between different types of innovation is necessary (Moller et al., 2007). The most established distinction is between radical and incremental innovation (Subramaniam \& Youndt, 2005). Radical innovation is defined as the development of new products that require significantly new technology or ideas that did not exist in the market before or require fundamental changes to the existing market (McDermott \& O'Connor, 2002). Incremental innovation is defined as minor changes or extensions to the current products, existing services or processes of the organisations (Dewar \& Dutton, 1986). Being a radical innovator is an important factor for firms' long-term survival. This type of innovation is an engine of economic growth and lays the foundation for other new product development (McDermott \& O'Connor, 2002). O'Reilly and Tushman (2004) argued that companies need to perform well in both types of innovation in order to be successful. They call this type of organisation an ambidextrous organisation, one which is able to pursue both radical and incremental innovation simultaneously.

A closely related distinction is that between exploration and exploitation, originally made by March (1991). Exploration may be characterized as breaking away from the established way of doing things and focusing on the creation of technological knowledge that is new to the firm (Gilsing et al., 2008). Exploitation, by contrast, may be characterized as a process of routinisation, which adds to the existing knowledge base and competence set of a firm without changing the nature of activities, by using current information, technologies, skills and abilities (Hair, Black, 
Babin, \& Anderson, 2010). We follow McGrath (2001), O’Reilly and Tushman (2004) and most other authors on innovation by equating radical innovation with exploration, and incremental innovation with exploitation.

\subsection{Innovation Management Framework}

To innovate effectively, all parts of an organisation have to participate actively in the innovation process: for example, innovation should not only come from the R\&D department in a manufacturing company or the strategic planning group of a service company (Goffin \& Mitchell, 2010). Different functional areas in an organisation can contribute significantly to its innovation activities. Innovation management practices refer to the solutions that companies usually use to manage the process of developing an innovation (Oke, 2002). Several innovation management frameworks have been developed. Drew (1995) uses the McKinsey 7-S model (Peters \& Waterman, 1982; Song, Benedetto, \& Zhao, 1999) as a framework to compare innovation management practices in various Canadian financial service firms. Oke (2007, p. 568) explains the elements in the 7-S framework as "Strategic planning practices relating to innovation, barriers to product innovation, organisation changes to promote innovation, drivers of new product development strategy, structures and systems for innovation, approaches to new product development and human resource strategies for innovation". Cooper's (1999) framework for innovation management practices uses a stage-gate approach. Oke (2007) stated that this approach has been adopted by many companies, but the principal limitation of Cooper's approach is that it mainly focuses on process factors; there are other organisational factors that impact on innovation performance that have to be taken into account (Oke, 2007). Goffin and Mitchell (2005) have introduced an innovation management framework, Pentathlon, which encompasses the main elements of innovation management and their relationships. This framework addresses the shortcomings of the previous models by providing a comprehensive, but simple framework that addresses soft organisational and process issues. The framework covers the five areas where companies need to 
perform well in order to be able to achieve successful business management (Goffin \& Mitchell, 2010) and has been adopted to investigate innovation management practice in previous studies (Oke, 2007).

Innovation Strategy: This helps the entire organisation to focus on the same innovation goal and provides it with a clear path through its innovation process.

Creativity/Idea Management: Idea generation is an important part of the innovation development process. Ideas are the raw material of innovation and have to be generated from both inside and outside the firm.

Portfolio Management: It is important to have an efficient process in place to choose the ideas for development that are in line with the innovation strategy of a company.

Implementation: This phase requires fundamental capabilities to quickly and efficiently develop and commercialise an idea into a new product, process or service innovation.

Human Resource Management: Many people and organisation climate issues related to the human resource management of a company (e.g. training policies, job design, creating an effective organisational structure) play a significant role in innovation performance.

Goffin and Mitchell (2010) argue that, of these five areas, innovation strategy is the heart of innovation management which affects and shapes all the other innovation management practices in a company. Previous studies (Cooper, Edgett, \& Kleinschmidt, 1999; Griffin, 1997) suggest that companies with high innovation performance have a clear strategy for new products/services that guides the company. From a networking perspective, innovation strategy guides partnerships with others to explore new opportunities (Goffin \& Mitchell, 2010). Thus innovation strategy guides innovation both directly, by providing a clear path for a company's innovation activities, and indirectly, by shaping other innovation management practices and networking activities. Therefore innovation management practice will impact on both radical and incremental innovation. 
In the next section, we broaden our focus from the firm itself to include the network within which it operates.

\subsection{Networks of firms and innovation}

The network perspective is based on the idea that economic activities are embedded in a social network of relationships (Gulati, Dialdin, \& Wang, 2002). Laumann et al. (1987 p. 458) define a social network as a "set of nodes (e.g., persons, organisations) linked by a set of social relationships (e.g., friendship, transfer of funds, overlapping membership) of a specified type".

Previous studies (Gilsing et al., 2008) argue that the network activities increase a firm's absorptive capacity "to recognize the value of new, external information, assimilate it, and apply it to commercial ends" (Cohen \& Levinthal, 1990). Forsman (2011) indicates that the benefits of networking for innovation development include opportunities to improve knowledge, access to new markets, lower costs of production and R\&D. Studies on inter-firm relationships suggest different motives for establishing inter-firm relationships e.g. spreading cost, sharing risks and knowledge sharing (Ahuja, 2000; Barringer \& Harrison, 2000; Beckman \& Haunschild, 2002). Acquisition of knowledge and capabilities from partner firms is the most cited reason for inter-firm collaboration (Mowery, Oxley, \& Silverman, 1996). Research findings suggest that firms which establish relationships with other organisations are more innovative (Ahuja, 2000; Powell et al., 1996).

An ego network approach is typically adopted in analysis as it helps to explain how being part of a network affects firms' actions and outcomes (Provan, Fish, \& Sydow, 2007). Ego networks are defined as networks consisting of one focal actor (ego) together with all partners in the first order neighbourhood of the ego and all the links among the partners (Everett \& Borgatti, 2005). Three aspects of ego networks are identified: 1) structural properties (Burt, 1992), 2) relational properties (Gulati et al., 2002), and 3) nodal properties (Beckman \& Haunschild, 2002). 
With regards to inter-organisational relationships, this article makes a clear distinction between formal and informal ties. Formal inter-organisational relationships are based on contractual obligations and are a means of planned knowledge exchange between organisations (Smith, Carroll, \& Ashford, 1995). It is argued that formal ties are more easily incorporated into an open innovation strategy (Simard \& West, 2006). To define inter-organisational relationships in the context of this study it is necessary to bear in mind that employees of an organisation are sources of informal interorganisational relationships and capturing data for these relationships is hard and time consuming. Therefore this study only focuses on formal relationships between companies. Inter-organisational relationships, in the context of this study, refer to all types of formal knowledge transfer relationships between companies. These relationships can be with any type of organisation: customers, suppliers, partners, universities or laboratories. This definition covers all the formal knowledge transfer relationships between a company and all of its partners.

\subsection{Network characteristics and innovation}

\subsubsection{Structural properties}

Betweenness centrality: This refers to the frequency with which a firm falls on the shortest path joining each pair of other firms in the network (Freeman, 1979). The main benefit of betweenness centrality is that a firm that lies between two other firms that are not connected to each other directly has control on the information and resource flow (Freeman, 1979). This may enable a firm to extract more value from the network because of its strategic position. Radical innovation requires the ability to combine and transform the new knowledge acquired from different resources. In this situation a network is not just a medium to transfer existing knowledge but can also help to transfer the required information and combine them together to provide the potential for a radical innovation. Firms' centrality helps them to find opportunities to develop non-redundant relations with other companies (Gilsing et al., 2008) which will contribute to the novelty of information that 
is being transferred to the company. Thus firms with higher betweenness centrality have more opportunities to develop radical innovations.

Ego network density: Network density measures the extent to which network partners are connected to each other (Gilsing et al., 2008). Previous research argues that network density will increase absorptive capacity by limiting novelty creation (Gilsing et al., 2008). Direct ties in the ego network not only provide access to partners' knowledge but also can act as a medium to gain access to the partners' partners' knowledge (Gulati \& Gargiulo, 1999). Argote and Ingram (2000) found that firms in a network can act as information processing devices. They can process the transferred knowledge from their partners and transfer it to the focal firm. This can be helpful when there is a large technological distance between firms.

Another benefit of being a member of a dense network is the reliability of the knowledge. Firms receiving the same knowledge from different resources may do triangulation to make sure that the transferred knowledge is reliable. Therefore network density can increase the absorptive capacity of a firm which will provide the opportunity for radical innovation. Therefore being part of a high density network will increase the chance for radical innovation.

Degree centrality: This is the number of the focal firm's direct partners in a network (Freeman, 1979). Companies with higher degree centrality have more visibility in the network (Gulati et al., 2002) and can attract more resource rich partners (Gulati, 1999). Another benefit of degree centrality is the experience gained in firm cooperation (Gulati et al., 2002). Power of endorsement is another benefit of having higher visibility in the network (Stuart, 2000). According to resource dependency theory (Pfeffer \& Salancik, 1987) the power of endorsement can provide opportunities for the focal firm that are not available to others.

Higher degree centrality helps focal firms to receive feedback about their products or services from different perspectives, which helps improve them. Moreover higher degree centrality provides 
the managers of the focal firm with more opportunities to interact with other managers and access their ways of doing things and different approaches to problem solving. Therefore higher degree centrality will increase the chance for incremental innovation.

\subsubsection{Relational properties}

Strength of ties: Rowley, Behrens and Krackhardt (2000) define tie strength between firms as "frequency of interaction between partners and their level of resource commitment to the relationship". Strong ties are sources of private information and critical resources and increase trust and reciprocity between firms (Gulati et al., 2002).

In an exploitation environment, firms that belong to a network with strong ties are more likely to perform better (Gulati et al., 2002). Frequent interactions with network partners and commitment of resources are necessary for building strong ties (Granovetter, 1985). They provide rich customised information (Rowley et al., 2000) and confirm the opinions of their group members (Julien, Andriambeloson, \& Ramangalahy, 2004) both of which are vital to refine their current technologies and reduce production costs. Therefore networks with a higher number of strong ties will help with incremental innovation.

On the other hand, relying on strong ties may block the focal firm's access to new information about the opportunities in the market (Gulati et al., 2002). Weak ties are sources of new information and opportunities in the market (Granovetter, 1985), and reduce firms' resource dependence on strong partners (Baker, 1990). In an exploratory environment firms are looking for new knowledge and information, thus strong ties are not helpful. Weak ties can be a medium for new knowledge from other companies and a trigger to mix new ideas that lead to change and radical innovation. Thus networks with a higher number of weak ties increase the opportunity for radical innovation.

Diversity of ties: Diversity of ties refers to different types of knowledge (e.g. training, market knowledge, technological knowledge) that may be transferred to the focal firm. Tie diversity will 
provide the focal firm with complementary resources and opportunities to overcome resource barriers and uncertainties in its business. Sammarra and Biggiero (2008) found that in an inter-firm relationship three different types of knowledge may be transferred (managerial, technological and market knowledge). They argued that all three are necessary for a successful innovation. According to this argument firms not only have different types of ties with different partners but they may also have a diversity of ties with a single partner. Furthermore, diversity of ties helps the focal firm to acquire a better perspective and holistic development (Srivastava, 2007). Therefore diversity of ties will increase the opportunity for radical innovation.

\subsubsection{Nodal properties}

Diversity of partners: Diversity of partners refers to the differences in the network members' abilities such as experience, resources and practices. According to Laursen and Salter (2006), diversity of partners can be measured by the nature of the main business of each partner and the type of the partner (supplier, customer, competitor, etc.). This has an impact on the focal firm's innovation (Kaufmann \& Todtling, 2001). Ego networks with diverse partners provide the focal firm with access to information and resources in different areas and shed light on different approaches and technologies (Pennings \& Harianto, 1992). This will provide the opportunity for the focal firm to use various channels to seek different solutions in its business (Laursen \& Salter, 2006). Firms in networks with diverse partners have the opportunity to observe various innovation approaches and their consequences which they can use to improve the quality of their innovation efforts (Beckman \& Haunschild, 2002). Therefore diversity of partners will help with radical innovation.

\subsection{Determinants of radical and incremental innovation}

The resource-based view (RBV) of the firm has been a widely-applied theory to address the fundamental question of why firms are different in their performance, including innovation, and how firms achieve and sustain competitive advantage by deploying their resources (Kostopoulos, 
Spanos, \& Prastacos, 2002). The theory is based on the so-called VRIN (valuable, rare, inimitable and non-substitutable) resources as the sources of competitive advantage to a firm. Innovation capabilities of a firm are inimitable and valuable. Though RBV primarily focuses on resources and capabilities internal to the firm, it has been argued that the internal focus of RBV can be complemented by looking for sources of value-creating resources beyond the boundaries of the firm, especially via the firm's network (Gulati, Nohria, \& Zaheer, 2000). Recently, scholars have drawn on network literature to highlight the importance of external resources available to the firm through its networks (Zaheer \& Bell, 2005). Zaheer and Bell (2005) posit that firms with superior network structures may be better able to exploit their internal capabilities and thus enhance their performance. Forsman (2011) also argues the necessity of combining the internal resources and capabilities with external input gained through networking. Therefore, this study attempts to adapt and extend the resource based view in the context of the firm's innovation performance by considering the firm's external resources available through networking and its internal capabilities of utilising these resources through innovation management. Capabilities refer to a firm's capacity to deploy and coordinate different resources, usually in combination, using organizational processes, to affect a desired end (Amit \& Schoemaker, 1993). In the context of innovation, the areas in the innovation management framework proposed by Goffin and Mitchell (2005) cover the organisational processes and capacity to deploy and coordinate relevant resources for innovation. Goffin and Pfeiffer (1999) argue that to achieve successful innovation management, companies must achieve good performance in these five areas. Therefore, from the resource based view, the innovation management practices are referred as innovation management capabilities in this study.

Based on the theoretical considerations discussed above, table 1 presents the determinant variables (independent) and outcome (dependent) variables to illustrate the research proposition, noting the absence of the specific hypotheses that would appear in a conventional statistical study. Our proposition is that the set of determinant variables has a causal relationship with the outcome 
variables, in that some combination(s) of values of the variables will discriminate between successful and unsuccessful innovators. By employing fsQCA, it is possible to examine how the different configurations of these determinant variables influence radical and incremental innovation.

Table 1.Determinants of radical and incremental innovation

\begin{tabular}{|c|c|c|}
\hline \multirow{2}{*}{ Determinant variables } & \multicolumn{2}{|c|}{$\begin{array}{c}\text { Outcome variables and their } \\
\text { determinants }\end{array}$} \\
\hline & $\begin{array}{c}\text { Radical } \\
\text { Innovation }\end{array}$ & $\begin{array}{l}\text { Incremental } \\
\text { Innovation }\end{array}$ \\
\hline \multicolumn{3}{|l|}{ Network characteristics } \\
\hline 1. Betweenness Centrality & $\sqrt{ }$ & \\
\hline Diversity of Ties & $\sqrt{ }$ & \\
\hline Ego Network Density & $\sqrt{ }$ & \\
\hline Degree Centrality & & $\sqrt{ }$ \\
\hline Number of Strong Ties & & $\sqrt{ }$ \\
\hline Number of Weak Ties & $\sqrt{ }$ & \\
\hline Diversity of Partners & $\sqrt{ }$ & \\
\hline \multicolumn{3}{|l|}{$\begin{array}{l}\text { Innovation management } \\
\text { capabilities }\end{array}$} \\
\hline Innovation Strategy & $\sqrt{ }$ & $\sqrt{ }$ \\
\hline Creativity/Idea Management & $\sqrt{ }$ & $\sqrt{ }$ \\
\hline Portfolio Management & $\sqrt{ }$ & $\sqrt{ }$ \\
\hline 4. Implementation & $\sqrt{ }$ & $\sqrt{ }$ \\
\hline 5. Human Resource Management & $\sqrt{ }$ & $\sqrt{ }$ \\
\hline
\end{tabular}

\section{Measurement of variables}

\subsection{Dependent variable: innovation performance}

Measuring innovation is one of the major problems of innovation research (Koberg, Detienne, \& Heppard, 2003). Researchers have used a variety of methods to measure innovative activities. For example, innovation performance has been measured through perceived performance against competitors (Subramaniam \& Youndt, 2005) or objective measures such as the number of patents developed (e.g. Ahuja, 2000; Gilsing et al., 2008; Stuart, 2000).

Due to the difficulties involved in collecting objective data for innovation performance of SMEs, this research adopted the method of subjective data using the main informant in SMEs by 
asking respondents to benchmark their performance against the competition in their industry. This approach uses perceptual and non-financial measures and has been widely adopted in innovation studies (e.g. Laosirihongthong, Prajogo, \& Adebanjo, 2014; Oke, 2007). Having reviewed the relevant literature on measures used for radical and incremental innovation and tested the measurement questions with pilot SMEs and subject experts, Table 2 shows the final items that were used to measure incremental and radical innovation performance (product, process and service) and the supporting sources of items. 
Table 2 Incremental and radical innovation measurement items

\begin{tabular}{|c|c|c|}
\hline \multicolumn{2}{|r|}{ Incremental Innovation Items } & Supporting references \\
\hline 1 & We often improve or revise existing products or services & Darroch and Jardine (2002). \\
\hline 2 & We add new products or services to our existing ranges & Darroch and Jardine (2002). \\
\hline 3 & $\begin{array}{l}\text { We make changes that reinforce our prevailing } \\
\text { product/service lines }\end{array}$ & $\begin{array}{l}\text { Subramaniam and Youndt } \\
\text { (2005). }\end{array}$ \\
\hline 4 & We often reposition existing products or services & Darroch and Jardine (2002). \\
\hline 5 & We exploit the potential of the established design & Henderson and Clark (1990). \\
\hline 6 & $\begin{array}{l}\text { We often change the way we make products or deliver } \\
\text { services }\end{array}$ & Darroch and Jardine (2002). \\
\hline 7 & $\begin{array}{l}\text { We introduce new or significantly improved processes for } \\
\text { producing or supplying products (goods or delivering } \\
\text { services) which are new to our firm }\end{array}$ & Reichstein and Salter (2006). \\
\hline \multicolumn{3}{|c|}{ Radical Innovation Items } \\
\hline 1 & $\begin{array}{l}\text { We develop products or services that offer greater } \\
\text { advantages to customers than any other products or services } \\
\text { currently available }\end{array}$ & Darroch and Jardine (2002). \\
\hline 2 & $\begin{array}{l}\text { We develop products or services that better meet the needs } \\
\text { of customers than any other product or service currently } \\
\text { available. }\end{array}$ & Darroch and Jardine (2002). \\
\hline 3 & $\begin{array}{l}\text { We develop products or services that require customers to } \\
\text { substantially alter their behaviour. }\end{array}$ & Darroch and Jardine (2002). \\
\hline 4 & We introduce new products/services to an existing market & $\begin{array}{l}\text { Oke, Burke, and Myers } \\
\text { (2007). }\end{array}$ \\
\hline 5 & We introduce new products/services to a new market & Oke et al. (2007). \\
\hline 6 & $\begin{array}{l}\text { We develop new product/services that require significantly } \\
\text { new technology or ideas that did not exist in the market } \\
\text { before }\end{array}$ & $\begin{array}{l}\text { McDermott and O'Connor } \\
\text { (2002). }\end{array}$ \\
\hline 7 & $\begin{array}{l}\text { We create new major product/service programs leading to } \\
\text { expansion of current markets }\end{array}$ & Koberg et al. (2003). \\
\hline 8 & $\begin{array}{l}\text { We develop innovations that make our prevailing } \\
\text { product/service lines obsolete }\end{array}$ & $\begin{array}{l}\text { Subramaniam and Youndt } \\
(2005) \text {. }\end{array}$ \\
\hline 9 & $\begin{array}{l}\text { We introduce new or significantly improved processes for } \\
\text { producing or supplying products (goods or delivering } \\
\text { services) which are new to our industry }\end{array}$ & Reichstein and Salter (2006). \\
\hline
\end{tabular}

Respondents were asked to rate their performance in comparison to their competitors in the same sector (1: much weaker to 5: much stronger). This makes the data comparable at crossindustry level.

\subsection{Independent variables}


Network data was collected through name generator and name interpreter questions. Companies were asked to write the initials of up to 10 partners with whom they had knowledge transfer in 2010 (name generator). Then there were questions about their partners' business, frequency of contact with each partner and whether the partner organisations have any relationship with each other (partner to partner relationship) (name interpreter questions). Table 3 shows the questions in the survey that were used to collect the data about the network structure of the organisations and their partners.

Table 3 Questions for collecting network data

\begin{tabular}{|l|l|}
\hline 1 & $\begin{array}{l}\text { Please write the initials of the companies, universities, institutes or } \\
\text { laboratories that you have had an inter-organisational relationship with in } \\
2010 .\end{array}$ \\
\hline 2 & $\begin{array}{l}\text { For each of the companies you have provided please fill in the rest of the } \\
\text { table according to the following guidelines. }\end{array}$ \\
\hline Business type: what is their main business? (consultancy, university...)
\end{tabular}

Betweenness Centrality: Betweenness centrality was calculated using the method of Everett and Borgatti (2005). 
Diversity of Ties: The number of types of knowledge transferred with each partner was counted. This method is similar to that of Beckman and Haunschild (2002).

Ego Network Density: This was obtained from the number of existing ties among partners of the ego, divided by the total number of possible ties among the partners.

Degree centrality: This was measured as the number of partners in the first order neighbourhood which are directly connected to the ego (Marsden, 2002). For an ego network, degree centrality is $\mathrm{N}-1$, where $\mathrm{N}$ is the number of nodes.

Number of Strong Ties and Number of Weak Ties. Tie strength was measured using the frequency of relationships with each of the partners. A similar approach has been used in the study by Ouimet et al. (2004). Ties with daily and weekly contacts are considered strong ties. Ties with monthly and quarterly contacts are considered weak ties. The number of each type was measured as a count of the number of partners in that category (Ouimet et al., 2004).

Diversity of Partners: Following the method of Laursen and Salter (2006), companies were asked about the main business of each partner and the type of the partner (supplier, customer, competitor, etc.). Using this information and the classification by Laursen and Salter (2006) the diversity of partners is calculated as the number of unique resources that they are using.

Innovation Management Capabilities: The study adopted the questions developed by Oke, Burke and Myers (2007) (please note that the full measurement items are not included in that reference, but were provided by Oke when requested) to measure the concepts in the Pentathlon framework (innovation strategy, creativity/idea management, portfolio management, implementation, human resource management). Table 4 shows the variables and their associated measures and Table 5 provides a summary of research variables and their descriptions. Respondents were asked to indicate their agreement with the statements listed in table 4 from 1: strongly disagree to 5: strongly agree. 
Table 4 Measures for innovation management capabilities (source: Oke et al., 2007)

\begin{tabular}{|c|c|}
\hline \multicolumn{2}{|l|}{ Description } \\
\hline $\begin{array}{l}\text { Innovation } \\
\text { Strategy }\end{array}$ & $\begin{array}{l}\text { 1. Introduction of innovation is a fundamental part of the } \\
\text { company's philosophy and values; } \\
\text { 2. There is clarity of corporate vision and goals relating to } \\
\text { innovation; } \\
\text { 3. Goals for innovation are communicated effectively throughout } \\
\text { the company; } \\
\text { 4. New initiatives are aligned with the overall business strategy; } \\
\text { 5. Top management is fully committed to support innovation } \\
\text { activities and programmes. }\end{array}$ \\
\hline $\begin{array}{l}\text { Cre } \\
\text { Mar }\end{array}$ & $\begin{array}{l}\text { 1. Developing new ideas is a key strength of this business; } \\
\text { 2. Technology is a key source of new ideas for our business; } \\
\text { 3. Employees are actively encouraged to generate new ideas; } \\
\text { 4. New ideas are collected internally on a regular basis; } \\
\text { 5. New ideas are most likely to emerge from talking to customers; } \\
\text { 6. Assistance to develop new ideas is readily available. }\end{array}$ \\
\hline $\begin{array}{l}\text { Por } \\
\text { mar }\end{array}$ & $\begin{array}{l}\text { 1. Decisions with regard to implementing new ideas are made } \\
\text { quickly; } \\
\text { 2. Reviews of new ideas are held on a regular basis; } \\
\text { 3. There is a good balance of ideas for new products, services and } \\
\text { processes; } \\
\text { 4. There is an effective feedback mechanism in place to monitor } \\
\text { actual product/service performance; } \\
\text { 5. We have a process for selecting ideas to be developed; } \\
\text { 6. The process for selecting ideas is transparent and understood by } \\
\text { all employees. }\end{array}$ \\
\hline Implementation & $\begin{array}{l}\text { 1. Projects to develop new ideas are reviewed on a regular basis; } \\
\text { 2. Project reviews for new ideas are used to improve performance } \\
\text { of new product/service development; } \\
\text { 3. Cross-functional working is encouraged for developing new } \\
\text { ideas; } \\
\text { 4. Project teams, which involve all parts of the company, are set up } \\
\text { for developing new ideas; } \\
\text { 5. Developing new ideas is a well-documented process; } \\
\text { 6. We control and monitor the process effectively to constantly } \\
\text { improve speed to market of new products. }\end{array}$ \\
\hline $\begin{array}{l}\text { Human } \\
\text { Resource } \\
\text { Management }\end{array}$ & $\begin{array}{l}\text { 1. Employees are aware of their role with regard to innovation; } \\
\text { 2. Innovation is a key criterion in our recruitment and selection } \\
\text { process; } \\
\text { 3. Human resource policies support a culture of innovation; } \\
\text { 4. Innovation forms a key part of our training and development } \\
\text { programmes; } \\
\text { 5. The broad meaning of innovation (i.e. product, services and } \\
\text { processes) is understood by all staff; } \\
\text { 6. Innovation is reviewed in staff performance reviews. }\end{array}$ \\
\hline
\end{tabular}


Table 5 A summary of research variables and descriptions

\begin{tabular}{|c|c|c|}
\hline \multicolumn{2}{|c|}{ Variables } & Description \\
\hline \multicolumn{3}{|r|}{ Dependent variables } \\
\hline 1 & $\begin{array}{l}\text { Incremental } \\
\text { Innovation }\end{array}$ & $\begin{array}{l}\text { Minor changes and extensions to the current } \\
\text { products/services/processes }\end{array}$ \\
\hline 2 & Radical Innovation & $\begin{array}{l}\text { New products/services/processes not existing before or } \\
\text { requiring fundamental changes to the existing market }\end{array}$ \\
\hline \multicolumn{3}{|c|}{ Independent variables - network characteristics } \\
\hline 1 & $\begin{array}{l}\text { Betweenness } \\
\text { Centrality }\end{array}$ & $\begin{array}{l}\text { The fraction of the shortest paths of knowledge } \\
\text { transfer between partners that pass through the focal } \\
\text { firm }\end{array}$ \\
\hline 2 & Diversity of Ties & $\begin{array}{l}\text { Different types of knowledge being transferred } \\
\text { between partners }\end{array}$ \\
\hline 3 & Ego Network Density & $\begin{array}{l}\text { Number of existing ties among partners of the ego, } \\
\text { divided by the total number of possible ties among the } \\
\text { partners }\end{array}$ \\
\hline 4 & Degree Centrality & Number of partners \\
\hline 5 & $\begin{array}{l}\text { Number of Strong } \\
\text { Ties }\end{array}$ & $\begin{array}{l}\text { Number of ties with intensive interactions between } \\
\text { partners }\end{array}$ \\
\hline 6 & Number of Weak Ties & $\begin{array}{l}\text { Number of ties with very few interactions between } \\
\text { partners }\end{array}$ \\
\hline 7 & Diversity of Partners & $\begin{array}{l}\text { Differences in focal firm's partners' abilities such as } \\
\text { experience, resources and practices }\end{array}$ \\
\hline \multicolumn{3}{|c|}{ Independent variables - innovation management capabilities } \\
\hline 1 & Innovation Strategy & $\begin{array}{l}\text { There is a well-defined innovation strategy in the } \\
\text { organisation }\end{array}$ \\
\hline 2 & $\begin{array}{l}\text { Creativity/Idea } \\
\text { Management }\end{array}$ & $\begin{array}{l}\text { There are procedures to collect ideas in the } \\
\text { organisation }\end{array}$ \\
\hline 3 & $\begin{array}{l}\text { Portfolio } \\
\text { Management }\end{array}$ & There are procedures to select from the collected ideas \\
\hline 4 & Implementation & There are procedures to implement selected ideas \\
\hline 5 & $\begin{array}{l}\text { Human Resource } \\
\text { Management }\end{array}$ & $\begin{array}{l}\text { There are procedures to address people and } \\
\text { organisational climate issues. }\end{array}$ \\
\hline
\end{tabular}

\section{Research Methodology}

\subsection{Research Design and Setting}

This study focused on SMEs in two industry sectors: software supply and consultancy, and manufacture of chemicals and chemical products. These sectors were chosen because the sample 
needed (potentially) to engage in radical and incremental innovation involving product, service and process. Empirical data was collected in late 2011 through online and postal survey if there was no email address available. In the questionnaire, respondents were asked about their knowledge transfer activities with their network in 2010 and their innovation performance in 2011. Moser and Kalton (1971) argue that a 12 month period is practical for respondents to remember the required information.

\subsection{Sample Selection}

The FAME database (Financial Analysis Made Easy) was utilised to obtain a sample of 1400 SMEs in the UK. One week after the main questionnaire a reminder was sent to the companies, and two weeks later another reminder and a copy of the questionnaire was sent to those who had not responded. In total over a period of three months 103 usable responses were collected. A total of 417 companies replied by telephone, sending back the blank questionnaire, email or mail stating that the addressee is not in the company anymore or they are too busy to fill in the questionnaire. Therefore the overall response rate was $10.4 \%$.

\subsection{Reliability test of the variables}

Following the guidelines by Hair, Ringle, and Sarstedt (2011), exploratory factor analysis was conducted on the research variables. Convergent validity of the model was examined using factor loadings and significance of the indicators. Non-significant items and items with loadings below 0.5 were removed from the measurement model The factors that did not meet the criteria were item 4 from Radical Innovation, items 4, 5 and 6 from Incremental Innovation, item 6 from Creativity/Idea Management and item 1 from Portfolio Management. Guidelines by Chin (Chin, 2010) were followed to make sure that the variables meet the criteria for discriminant validity that requires the factor loading of each indicator on its associated variable was higher than its loading on any other variables. Table 6 shows the results of factor loadings of the remaining items and variable reliability tests. The value of Cronbach's alpha should be above 0.6 (Nunnally \& Bernstein, 1994) and 
composite reliability should be above 0.7 (Hair et al., 2011) for all the research variables. The results shown in Table 6 indicate that the dimensionality and reliability of all variables are acceptable.

Table 6. Reliability test of the variables

\begin{tabular}{|l|c|c|c|}
\hline & $\begin{array}{c}\text { Factor } \\
\text { loading* }\end{array}$ & $\begin{array}{c}\text { Composite } \\
\text { Reliability }\end{array}$ & $\begin{array}{c}\text { Cronbach's } \\
\text { Alpha }\end{array}$ \\
\hline Radical Innovation (8 items) & $0.625-0.857$ & 0.910 & 0.886 \\
\hline Incremental Innovation (4 items) & $0.602-0.792$ & 0.814 & 0.691 \\
\hline Innovation Strategy (5 items) & $0.767-0.896$ & 0.910 & 0.867 \\
\hline $\begin{array}{l}\text { Creativity/Idea Management (5 } \\
\text { items) }\end{array}$ & $0.721-0.788$ & 0.871 & 0.815 \\
\hline Portfolio Management (5 items) & $0.569-0.799$ & 0.831 & 0.744 \\
\hline Implementation (6 items) & $0.755-0.808$ & 0.901 & 0.867 \\
\hline HRM (6 items) & $0.661-0.906$ & 0.920 & 0.893 \\
\hline
\end{tabular}

*All the factor loadings were significant at $\mathrm{P}<.001$

\subsection{Fuzzy Set Qualitative Comparative Analysis}

The data was analysed using Fuzzy Set Qualitative Comparative Analysis (fsQCA). This method examines the interaction between different causal and outcome factors. Using fsQCA enables the researcher to find different combinations of causal conditions that may lead to the same outcome (Berg-Schlosser, De Meur, Rihous, \& Ragin, 2009). Conventional statistical methods are concerned with the net effect of an independent variable on an outcome, while fsQCA takes a different approach and considers multiple and different causal paths that are satisfactory for that causal condition (Berg-Schlosser et al., 2009).

In this study a combination of network characteristics and innovation management capabilities were hypothesised as the causal conditions that influence the radical and incremental innovation performance of companies. Statistical analysis can reveal how different variables impact on their radical and incremental innovation performance. However, it is hard for companies, especially SMEs, to pursue a higher level of every antecedent to achieve higher performance. Different combinations of these factors should be studied to determine which combinations of them contribute to higher performance on different types of innovation. The fsQCA method attempts to 
describe different combinations of the factors that exist among the comparable cases that result in higher radical and incremental innovation performance. (2008)

\section{Analysis and results}

\subsection{Transforming data into fuzzy set}

After constructing the data set the next step in fsQCA analysis is calibrating the causal and outcome conditions. In this study, the network characteristics and innovation management capabilities are the causal conditions and the radical and incremental innovation performance are the outcome conditions. The direct method was adopted as the method of calibration (Ragin, 2008). For the variables that were measured based on a Likert scale (radical and incremental innovation performance and innovation management capabilities variables) the original values of 5,3 , and 1 were set as full membership, cross-over point and full non-membership respectively. Table 7 presents the anchor point for each of these variables.

Table 7. Anchor points for calibrating those variables measured by Likert scale

\begin{tabular}{|l|c|ccc|}
\hline Variable & Range & $\begin{array}{c}\text { Full non- } \\
\text { membership }\end{array}$ & $\begin{array}{c}\text { Cross over } \\
\text { point }\end{array}$ & $\begin{array}{c}\text { Full } \\
\text { membership }\end{array}$ \\
\hline $\begin{array}{l}\text { Incremental } \\
\text { Innovation }\end{array}$ & $1-5$ & 1 & 3 & 5 \\
\hline Radical Innovation & $1-5$ & 1 & 3 & 5 \\
\hline $\begin{array}{l}\text { Innovation } \\
\text { management } \\
\text { capabilities }\end{array}$ & $1-5$ & 1 & 3 & 5 \\
\hline
\end{tabular}

For network variables it is difficult to determine what constitutes, for example, high betweenness centrality or low diversity of ties. A thorough literature review seeking to find any relevant literature about this issue was unsuccessful. Therefore, following the suggestions of Rihoux and Ragin (2009) the distribution in each condition was used as a guideline to set the threshold points. The cluster analysis function in the Tosmana (Cronqvist, 2005) 'Thresholdsetter' software, 
was used in order to find the gaps according to the distribution of the conditions. This function calculates the distribution of scores and clusters them into a pre-determined number of groups (in this research 3). The data was first imported into Tosmana to determine the anchor points for calibration of each network variable. Then the fsQCA software (Ragin, Drass, \& Davey, 2006) was used for calibration of the variables and fuzzy set qualitative comparative analysis and . Table 8 shows the anchor points of each network variable acquired from Tosmana.

Table 8. Anchor points for calibrating the network variables

\begin{tabular}{|l|c|c|c|c|}
\hline \multicolumn{1}{|c|}{ Variable } & Range & $\begin{array}{c}\text { Full non- } \\
\text { membership }\end{array}$ & $\begin{array}{c}\text { Cross over } \\
\text { point }\end{array}$ & $\begin{array}{c}\text { Full } \\
\text { membership }\end{array}$ \\
\hline Betweenness centrality & $0-45$ & 8.50 & 17 & 31 \\
\hline Diversity of Ties & $0-4$ & 0.50 & 1.50 & 3.50 \\
\hline Ego Network Density & $0-1$ & 0.09 & 0.53 & 0.83 \\
\hline Degree Centrality & $0-10$ & 1.50 & 3.50 & 8 \\
\hline Number of Strong Ties & $0-8$ & 1.6 & 3.5 & 7 \\
\hline Number of Weak Ties & $0-4$ & 0.50 & 2.50 & 3.50 \\
\hline Diversity of Partners & $0-8$ & 0.50 & 2.50 & 5.50 \\
\hline
\end{tabular}

Table 9 presents raw values and calibrated values for one case to clarify the calibration process. 
Table 9. Raw values and calibrated scores for one case

\begin{tabular}{|l|l|l|}
\hline Variable & Raw value & Calibrated value \\
\hline Incremental Innovation & 3 & 0.5 \\
\hline Radical Innovation & 2.6 & 0.36 \\
\hline Betweenness Centrality & 4 & 0.01 \\
\hline Diversity of Ties & 2 & 0.68 \\
\hline Ego Network Density & 0.3 & 0.17 \\
\hline Degree Centrality & 5 & 0.73 \\
\hline Number of Strong Ties & 2 & 0.09 \\
\hline Number of Weak Ties & 3 & 0.82 \\
\hline Diversity of Partners & 4 & 0.82 \\
\hline
\end{tabular}

\subsection{Constructing the Truth-Table}

Two truth tables were generated using fsQCA software with radical innovation and incremental innovation as the causal outcome for each table. Ragin (2008) suggests that gaps in the high consistency values are useful for establishing a consistency threshold and those below 0.75 show substantial inconsistencies. Following this guideline, the consistency threshold was set at 0.90 for the radical innovation truth table and at 0.98 for the incremental innovation truth table. In addition to the consistency value condition, only those configurations with 2 or more cases were included in the final stage of the analysis.

\subsection{Results}

The fsQCA software produces three solutions: 1) complex solution (zero logical remainders ${ }^{1}$ are used), 2) intermediate solution (only include the logical remainders that make sense in the final

\footnotetext{
${ }^{1}$ Ragin (2008) defines remainder in fsQCA as "a logically possible combination of conditions lacking empirical instances - either because the researcher has inadequate information about such cases or because the cases simply do not exist".
} 
solution) and 3) parsimonious solution (all logical remainders may be used without any evaluation of their possibility). Intermediate solutions are superior to other solutions in that they do not allow removal of necessary conditions (Ragin, 2008), and so intermediate solutions were used in this study.

Table 10 summarises the intermediate solution with radical innovation as the outcome. Black circles "O" represent the presence of the causal condition and white circles "O" represent the absence or negation of causal conditions. The blank cells represent "doesn't matter" conditions.

Table 10. Intermediate solution with radical innovation performance as the causal outcome

\begin{tabular}{|c|c|c|c|c|c|c|c|c|c|}
\hline \multicolumn{10}{|c|}{ Configurations } \\
\hline & 1 & 2 & 3 & 4 & 5 & 6 & 7 & 8 & 9 \\
\hline $\begin{array}{l}\text { Innovation } \\
\text { Management } \\
\text { Capabilities }\end{array}$ & & & & & & & & & \\
\hline Innovation Strategy & & - & 0 & - & 0 & 0 & 0 & 0 & 0 \\
\hline $\begin{array}{l}\text { Creativity/Idea } \\
\text { Management }\end{array}$ & O & O & 0 & - & 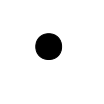 & O & & $\bullet$ & $\bullet$ \\
\hline Portfolio management & O & O & 0 & $\bullet$ & 0 & 0 & - & 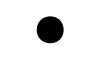 & O \\
\hline Implementation & O & O & 0 & 0 & 0 & O & O & 0 & $\bullet$ \\
\hline $\begin{array}{l}\text { Human Resource } \\
\text { Management }\end{array}$ & O & O & O & 0 & O & O & O & 0 & 0 \\
\hline $\begin{array}{l}\text { Social Network } \\
\text { Characteristics }\end{array}$ & & & & & & & & & \\
\hline Betweenness Centrality & O & $\mathrm{O}$ & O & O & 0 & O & $\mathrm{O}$ & O & O \\
\hline Diversity of Ties & $\bullet$ & 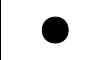 & 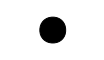 & & & & 0 & 0 & 0 \\
\hline Ego Network Density & O & O & & O & O & O & O & O & $\bullet$ \\
\hline Number of Weak Ties & & & & & & 0 & 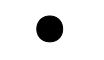 & 0 & $\bullet$ \\
\hline Diversity of partners & $\bullet$ & & O & O & $\bullet$ & $\bullet$ & $\bullet$ & & $\bullet$ \\
\hline Raw Consistency & 0.96 & 0.94 & 0.92 & 0.90 & 1 & 0.97 & 0.97 & 0.97 & 1 \\
\hline Raw Coverage & 0.24 & 0.31 & 0.40 & 0.47 & 0.06 & 0.21 & 0.21 & 0.26 & 0.11 \\
\hline Unique Coverage & 0.01 & 0.03 & 0.03 & 0.12 & 0.03 & 0.01 & 0.00 & 0.02 & 0.01 \\
\hline
\end{tabular}

Solution coverage: 0.73

Solution consistency: 0.89 
Regarding radical innovation, Table 9 shows that all consistency values are above 0.9 indicating that these configurations are sufficient conditions causing high radical innovation performance. Solution coverage is above 0.7 which indicates that the solution explains a large proportion of radical innovation performance (Ragin, 2008). In terms of raw coverage, the higher the raw coverage, the larger the proportion of the radical innovation performance that the configuration explains.

Configuration 1 shows that high diversity of ties and high diversity of partners can lead to better radical innovation even if the company has no innovation management capabilities in place. This suggests a critical role of the diversity of ties and partners in radical innovation that seems plausible because of the nature of radical innovation.

Configuration 2 suggests that the innovation strategy coupled with high diversity of ties can also lead to better radical innovation even in the absence of other innovation management capabilities and network properties. This is consistent with innovation strategy being at the heart of innovation management (Goffin \& Mitchell, 2010).

Configuration 3 suggests that the presence of innovation strategy, creativity/idea management, portfolio management and implementation and the absence of HRM together with low betweenness centrality, low diversity of partners and high diversity of ties will result in higher performance in radical innovation. Configuration 5, similarly to configuration 3, indicates that the presence of innovation strategy, creativity/idea management, portfolio management and implementation, and the absence of HRM, coupled with high betweenness centrality, high diversity of partners and low ego network density will result in higher performance in radical innovation.

Configurations 4 (which has the highest raw coverage) and 8 show that companies that have all innovation management capabilities in place, as well as low betweenness centrality and low ego network density, coupled with either low diversity of partners or high number of weak ties and high 
diversity of ties have higher radical innovation performance. It seems the strength of the innovation management capabilities can sometimes make up for a relatively poor network, though configuration 8 stresses the importance of weak ties for radical innovation (Granovetter, 1973).

Configuration 6 and 7 suggest that the presence of innovation strategy and portfolio management together with low betweenness centrality, low ego network density, high number of weak ties, high diversity of partners and high diversity of ties (in configuration 7 only) and the absence of other innovation management capabilities will lead to higher radical innovation performance.

The last configuration for higher radical innovation performance is configuration 9 which indicates that with high ego network density, the presence of innovation strategy, creativity/idea management, implementation and HRM, together with low betweenness centrality, high diversity of ties, high number of weak ties and high diversity of partners will lead to higher radical innovation performance. This suggest that if a company is actively involved in networking activities, it needs relevant management capabilities to ensure the company is effectively utilising its relational resources for innovation creation.

The results in table 10 also demonstrate the important presence of a number of key determinant variables in leading to higher radical innovation. The most important one is innovation strategy that is needed for all configurations except 1 and never appears as a negation condition. Another important innovation management capabilities variable is portfolio management that is present in 6 out of 9 configurations. The most important network characteristic is diversity of ties that is present in 6 of 9 configurations and has no absence or negation condition. 
Table 11. Intermediate solution with incremental innovation as the causal outcome

\begin{tabular}{|c|c|c|c|c|c|c|c|}
\hline \multicolumn{8}{|c|}{ Configurations } \\
\hline & 1 & 2 & 3 & 4 & 5 & 6 & 7 \\
\hline \multicolumn{8}{|l|}{$\begin{array}{l}\text { Innovation } \\
\text { Management } \\
\text { Capabilities }\end{array}$} \\
\hline Innovation Strategy & $\mathbf{0}$ & O & • & - & 0 & 0 & $\bullet$ \\
\hline $\begin{array}{l}\text { Creativity/Idea } \\
\text { Management }\end{array}$ & 0 & & $\bullet$ & $\bullet$ & 0 & O & O \\
\hline Portfolio management & 0 & O & 0 & & & O & $\bullet$ \\
\hline Implementation & $\bullet$ & O & & - & 0 & O & O \\
\hline $\begin{array}{l}\text { Human Resource } \\
\text { Management }\end{array}$ & & O & O & & $\bullet$ & O & O \\
\hline $\begin{array}{l}\text { Social Network } \\
\text { Properties }\end{array}$ & & & & & & & \\
\hline Degree Centrality & & O & $\bullet$ & 0 & 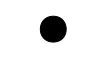 & 0 & O \\
\hline Number of Strong Ties & & & & $\bullet$ & & & \\
\hline Raw Consistency & 0.97 & 0.95 & 1 & 1 & 0.98 & 0.99 & 1 \\
\hline Raw Coverage & 0.65 & 0.37 & 0.27 & 0.11 & 0.29 & 0.18 & 0.32 \\
\hline Unique Coverage & 0.18 & 0.09 & 0.01 & 0.00 & 0.00 & 0.00 & 0.01 \\
\hline
\end{tabular}

Solution coverage: 0.81

Solution consistency: 0.95

Regarding incremental innovation, table 11 summarises the intermediate solutions with incremental innovation as the outcome. Table 11 indicates that all consistency values are at least 0.95, suggesting that these configurations are sufficient conditions causing high radical innovation performance. Solution coverage is above 0.8 which indicates that the solution explains a large proportion of incremental innovation performance.

Configuration 1, which has the highest unique and raw coverage in the solution, indicates that the presence of innovation strategy, creativity/idea management, portfolio management and implementation will lead to higher incremental innovation performance. In contrast to configuration 
1, configuration 2 implies that a lower degree centrality can on its own create higher incremental innovation performance given the absence of other factors. This is understandable because if a company is not active at networking with partners, there may be no need to have high innovation management capabilities in place covering strategy, portfolio, implementation and human resource management.

Configuration 3 shows that high degree centrality needs to be present with innovation strategy, creativity/idea management and portfolio management for higher incremental innovation performance. Configuration 4 shows that high degree centrality and number of strong ties need to be managed by innovation strategy, creativity/idea management and implementation for a higher incremental innovation performance.

Configuration 5 indicates that innovation strategy, creativity/idea management, implementation and human resource management combined with high degree centrality can lead to higher incremental innovation performance.

Configuration 6 suggests that the presence of innovation strategy and high degree centrality and the absence of other innovation management capabilities is another way of achieving higher incremental innovation performance.

The last configuration in the solution is configuration number 7 . This configuration suggests that a combination of innovation strategy and portfolio management, and low degree centrality, in the absence of creativity/idea management, implementation and human resource management, is another way of achieving higher incremental innovation performance.

Similar to radical innovation, innovation strategy plays an important role and is present in 6 of 7 configurations. High degree centrality is also present in 4 out of 7 configurations. 


\section{Discussion}

As explained earlier, there are several prior studies that document different factors impacting on an organisation's radical and incremental innovation performance. However, these studies focus on the influence of individual factors on different types of innovation performance. They implicitly imply, therefore, that organisations should seek to perform well in all the areas to be able to achieve the anticipated outcome. However, such a performance in all the areas is unlikely for enterprises, specifically for SMEs, due to their limited resources. The fsQCA enables researchers to understand which factors are relevant to achieving the desired outcome and what combinations of these factors will lead to that outcome (Fiss, 2011). Ganter and Hecker (2014) argue that fsQCA is particularly suitable for configurational analysis of organisational innovation. Organisations are generally only able to focus their expertise and resources on some of these factors and therefore it is important to understand what combination of these characteristics can assist them to achieve their goals. This study looks at different configurations of these factors and identifies the different paths that can lead to higher radical or incremental innovation performance. In addition to that, this research is one of the few studies that applies the fsQCA method to network characteristics.

The findings of the study identify several causal paths to achieve high performance in radical and incremental innovation. These results imply that there is no single factor that guarantees the anticipated outcome which means no one factor is the key to higher radical and/or incremental innovation performance and there are different paths to achieve the desired outcome.

Nevertheless, this study recognises certain common rules behind different configurations for both radical and incremental innovation. Along with the presence of other conditions, the innovation strategy is the most important condition for high radical and incremental innovation performance. This result reinforces the recognition by Goffin and Mitchell (2010) that the innovation strategy is the heart of innovation management and guides partnerships with others to explore new opportunities. Another interesting observation from Table 10 is that for radical 
innovation, innovation strategy, diversity of ties and number of weak ties never appear negatively in any configurations.

Moreover, the result shows how the combination of the network variables with innovation management capabilities can result in a desirable outcome. This supports the findings of Zaheer and Bell (2005) suggesting that a superior network position alone is not normally enough (none of the 16 configurations precisely fits this pattern) and companies must also possess the necessary internal capabilities in order to benefit from their network and enhance their performance. Analysis reveals that the combination of high degree centrality with other factors provides different avenues of achieving higher incremental innovation performance. This shows that although degree centrality alone cannot make a difference, when other factors are present, it can play a significant role in higher incremental innovation performance.

Oke (2007) in his study found a significant relation between all the innovation management capabilities and radical innovation performance. The result in this study shows that although innovation management capabilities are important for radical innovation, the presence of all five capabilities is not necessary to achieve this goal. Out of nine configurations in the radical innovation solution, only two solutions demand the presence of all the innovation management capabilities, and there are seven other combinations including all values from four to none of the innovation management capabilities. This finding is useful for enterprises because there may be no need for them to be perfect in all the conditions to achieve better radical innovation performance.

Another contrasting finding is that Oke (2007) did not find any significant relation between innovation management capabilities and incremental innovation performance. However, the findings in this study show that various combinations of these factors can lead to higher incremental innovation performance. One implication of this finding is that innovation management capabilities provide the necessary environment for the organisation to leverage the knowledge and other 
resources that it accesses through its strong ties. This shows that these factors are necessary to complement each other in order to achieve a higher performance in incremental innovation.

Fig 1 and Fig 2 present four examples of XY plots for radical and incremental solutions. Due to the high number of configurational paths, we only present plots for the two configurations with the highest coverage and consistency from each type of innovation. The plotted configurations show that the majority of observations are in the upper triangular part of the plot. These cases indicate that no causal condition is necessary for higher radical or incremental innovation. In all the plots there are few cases in the lower triangular part which indicates the sufficiency of the identified solutions.

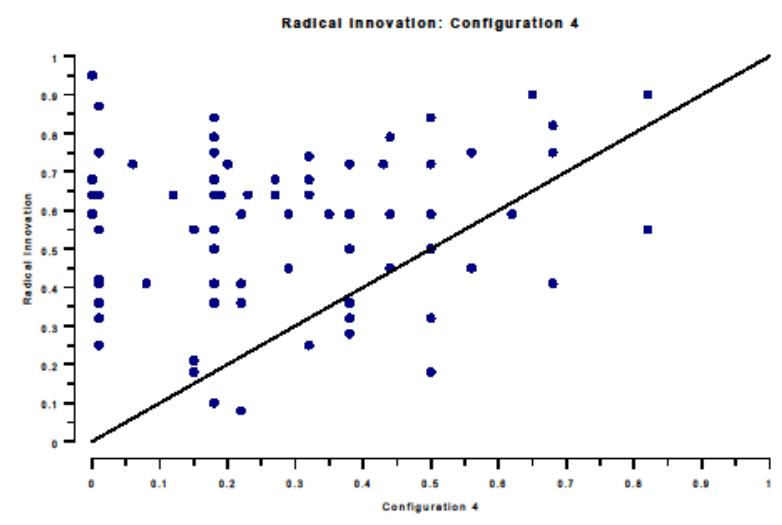

Fig. 1a. Radical innovation configuration 4

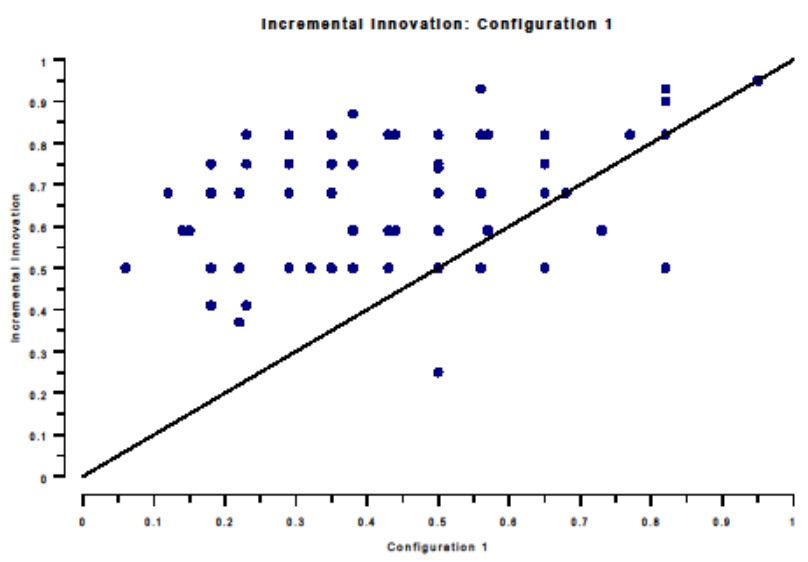

Fig. 2a. Incremental innovation configuration 1

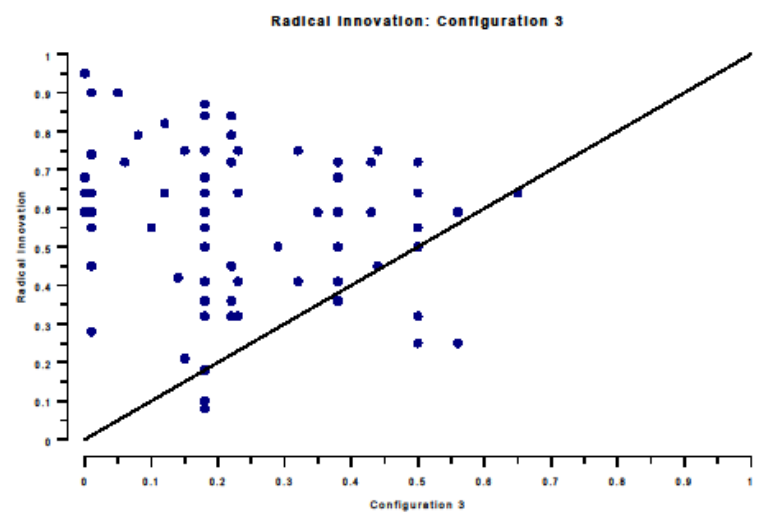

Fig. 1b. Radical innovation configuration 3

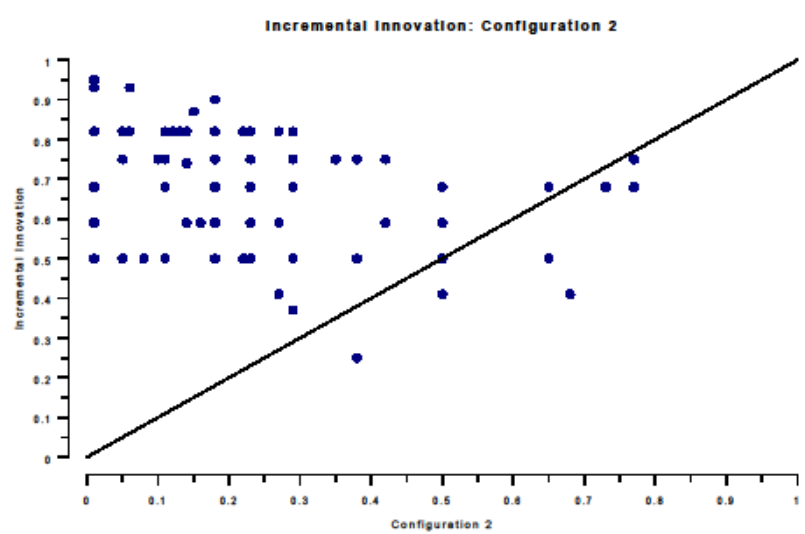

Fig. 2b. Incremental innovation configuration 2 
Overall, the study makes new contributions to innovation research and practice. Firstly, this study has highlighted that the RBV theory can be complemented by looking for the source of valuecreation from a firm's external networks. From a resource based view and in the context of innovation in SMEs, this study argues the necessity of understanding the impact of external resources and internal capabilities on different types of innovation performance by focusing on the external resources available through networking and the internal capabilities of innovation management. This theoretical consideration helps to understand how a firm's network and innovation management capabilities work in complementary ways in addressing the company's resource shortage and consequently providing different avenues to improve its innovativeness. Secondly, it contributes to network and innovation literature by examining the relationship between network characteristics and different types of innovation. Previous network and innovation studies largely focused on innovation as a general concept and ignored the effect of network resources on the types of innovation. Questions such as whether the characteristics of inter-organisational knowledge transfer networks influence a firm's generation of different types of innovation are largely unanswered. This study contributes significantly to this body of literature by examining how different network characteristics influence radical and incremental innovation respectively. Thirdly, the study is one of the few studies that employ fsQCA to analyse social network data, thus representing a new contribution to network research by providing a guideline for collecting and analysing network data using the fsQCA method. The fsQCA technique provides a unique tool that enables researchers to provide many alternative paths leading to higher innovation. It would not be possible to gain these valuable insights without using fsQCA. The research demonstrates the process and benefits of fsQCA that provide an additional perspective for researchers to explore the use of fsQCA in other relevant areas.

The findings have a number of managerial implications for SMEs. Firstly, companies should be aware of the fact that a network alone is normally not enough to improve their innovation 
performance and they need to improve their internal innovation management capabilities as well as their network resources. Internal innovation management capabilities, especially the innovation strategy, can be one of the main ingredients of any innovation without which companies would not be able to absorb the knowledge and harness the internal and external resources for innovation creation.

Secondly, the results of this study suggest that there are a number of different paths that lead to better incremental and radical innovation performance. The findings in this regard show that there is no need for companies to provide all the factors that may be helpful for incremental/radical innovation. There are different settings and configurations that companies can select based on their abilities, resources and expertise. Companies need to choose the one that is closest to their abilities and fits best with their resources. This will enable SMEs to use their limited resources more effectively and help them to prioritise their business strategies.

\section{Limitations and future research}

There are several limitations in this study. One of them is the use of the key informant method to collect the subjective data for innovation management capabilities and different types of innovation. This method was chosen because of the difficulty in collecting objective data on different types of innovation and innovation management capabilities across multiple industries.

Another limitation is the use of the ego network to study the network effects. Although this approach provides valuable insights into a firm's network characteristics, it should be noted that an ego network is embedded in a bigger network or "whole network" and some of the behavioural properties of ego network members can be influenced by other members in the whole network. The implications of the "whole network" effect are not considered in this study. Future research could develop a similar study using a socio-centric (whole network) approach and compare the results with this study. 
This study focuses on a firm's formal network, but companies and especially managers of SMEs are involved in a network of both formal and informal relationships. These informal relationships can also be a valuable resource for information and help to build the foundation for a formal partnership between companies. Therefore, taking informal as well as formal networks into account could shed more light on different aspects of innovation performance.

The study was conducted on two industries in high-tech sectors, which may limit the generalisability of the results. Future studies could conduct similar research in different industries or different sectors (medium-tech and low-tech) to examine how companies in other sectors may differ in leveraging their network resources for different types of innovations. Designing a longitudinal study would make a further contribution to the understanding of inter-organisational relationships and different types of innovations. The development of a time-series database would provide an additional understanding on, for example, the effect of the change in the portfolio of interorganisational relationships on radical and incremental innovation performance.

\section{Conclusion}

This research is one of the few studies that apply the fsQCA method to network characteristics. Based on the theoretical considerations of the resource based view and network theory, a number of the firm's network characteristics and innovation management capabilities are identified as the determinants of radical and incremental innovation performance. The fsQCA approach enables this study to understand what combinations of these determinants will lead to the desired outcome (Fiss, 2011). The findings from fsQCA show that although individual network factors and innovation management capabilities are important, there is no need for a company to perform well in all the areas. This analysis, using different combinations of network factors and innovation management capabilities, reveals that there are many paths to achieve better incremental and radical innovation performance. At first sight the 16 configurations identified may seem a large number, but with the factors in this study, there are 59049 possible configurations for radical 
innovation and 2187 for incremental innovation, so this is a very small proportion of the total number indeed. Companies need to choose one that is closest to their abilities and fits with their resources. It shows how different configurations of internal capabilities and network resources can lead to a better innovation performance. The results also suggest that a superior network position alone is not normally enough and companies must also possess the necessary internal innovation management capabilities in order to benefit from their network and enhance their innovation performance.

\section{References}

Abernathy, W. J., \& Clark, K. B. (1985). Innovation:Mapping the winds of creative destruction. Research Policy, 14(1), 3-22.

Ahuja, G. (2000). Collaboration networks, structural holes, and innovation: A longitudinal study. Administrative Science Quarterly, 45(3), 425-455.

Ahuja, G., \& Katila, R. (2001). Technological acquisitions and the innovation performance of acquiring firms: A longitudinal study. Strategic Management Journal, 22(3), 197-220.

Amara, N., Landry, R., Becheikh, N., \& Ouimet, M. (2008). Learning and novelty of innovation in established manufacturing SMEs. Technovation, 28(7), 450-463.

Amit, R., \& Schoemaker, P. J. (1993). Strategic assets and organizational rent. Strategic Management Journal, 14(1), 33-46.

Argote, L., \& Ingram, P. (2000). Knowledge Transfer: A Basis for Competitive Advantage in Firms. Organizational Behavior and Human Decision Processes, 82(1), 150-169.

Baker, W. E. (1990). Market Networks and Corporate Behavior. American Journal of Sociology, 96(3), 589-625.

Barringer, B. R., \& Harrison, J. S. (2000). Walking a tightrope: Creating value through interorganizational relationships. Journal of Management, 26(3), 367-403.

Beckman, C. M., \& Haunschild, P. R. (2002). Network Learning: The Effects of Partners' Heterogeneity of Experience on Corporate Acquisitions. Administrative Science Quarterly, 47(1), 92-124.

Berg-Schlosser, D., De Meur, G., Rihous, B., \& Ragin, C. C. (2009). Qualitative comparative analysis (QCA) as an approach. In B. R. C. C. Ragin (Ed.), Configurational Comparative Methods: Qualitative Comparative Analysis (QCA) and related techniques (Applied Social Research Methods) (pp. 1 -18). London: Sage.

Boschma, R. A., \& Wal, A. L. J. t. (2007). Knowledge Networks and Innovative Performance in an Industrial District: The Case of a Footwear District in the South of Italy. Industry \& Innovation, 14(2), 177-200.

Burt, R. S. (1992). Structural holes : the social structure of competition. Cambridge, Mass.: Harvard University Press.

Cheng, C.-F., Chang, M.-L., \& Li, C.-S. (2013). Configural paths to successful product innovation. Journal of Business Research, 66(12), 2561-2573.

Chin, W. W. (2010). How to writeup and report PLS analyses. London: Springer Verlag.

Cohen, W. M., \& Levinthal, D. A. (1990). Absorptive capacity: a new perspective on learning and innovation. Administrative Science Quarterly, 128-152. 
Cooper, R. G. (1999). Product leadership: Creating and launching superior new products. Reading, MA: Perseus Books.

Cooper, R. G., Edgett, S. J., \& Kleinschmidt, E. J. (1999). New product portfolio management: Practices and performance. Journal of Product Innovation Management, 16(4), 333-351.

Cronqvist, L. (2005). Tosmana- Tool for Small-N Analysis [Version 1.2]. http://www.tosmana.net Retrieved from http://www.tosmana.net

Darroch, J., \& Jardine, A. (2002). Combining Firm-Based and Consumer-Based Perspectives to Develop a New Measure for Innovation. Paper presented at the Paper presented at the 3rd International Conference on Management of Innovation and Technology, Hangzhou City, China.

De Propris, L. (2002). Types of innovation and inter-firm co-operation. Entrepreneurship and Regional Development, 14(4), 337-353.

Dewar, D., \& Dutton, J. E. (1986). The Adoption of Radical and Incremental Innovations: An Empirical Analysis. Management Science, 32(11), 1422-1433.

Drew, S. A. W. (1995). Strategic benchmarking: innovation practices in financial institutions. International Journal of Bank Marketing, 13(1), 4-16.

Everett, M., \& Borgatti, S. P. (2005). Ego network betweenness. Social Networks, 27(1), 31-38.

Fiss, P. C. (2011). Building better causal theories: A fuzzy set approach to typologies in organization research. The Academy of Management Journal (AMJ), 54(2), 393-420.

Forsman, H. (2011). Innovation capacity and innovation development in small enterprises. A comparison between the manufacturing and service sectors. Research Policy, 40(5), 739750 .

Freeman, L. C. (1979). Centrality in Social Networks Conceptual Clarification. Social Networks, $1(3), 215-239$.

Ganter, A., \& Hecker, A. (2014). Configurational paths to organizational innovation: qualitative comparative analyses of antecedents and contingencies. Journal of Business Research, 67(6), 1285-1292.

Gilsing, V., Nooteboom, B., Vanhaverbeke, W., Duysters, G., \& van den Oord, A. (2008). Network embeddedness and the exploration of novel technologies: Technological distance, betweenness centrality and density. Research Policy, 37(10), 1717-1731.

Goffin, K., \& Mitchell, R. (2005). Innovation Management: Strategy and Implementation using the Pentathlon Framework (1st edition ed.): Palgrave.

Goffin, K., \& Mitchell, R. (2010). Innovation Management Strategy and Implementations Using the Pentathlon Framework (2nd ed.): Palgrave Macmillan.

Goffin, K., \& Pfeiffer, R. (1999). Innovation Management in UK and German Manufacturing Companies. London: Anglo-German Foundation.

Granovetter, M. (1985). Economic Action and Social Structure: The Problem of Embeddedness. American Journal of Sociology, 91(3), 481-510.

Granovetter, M. S. (1973). The Strength of Weak Ties. American Journal of Sociology, 78(6), 1360-1380.

Griffin, A. (1997). PDMA research on new product development practices: Updating trends and benchmarking best practices. Journal of Product Innovation Management, 14(6), 429-458.

Gulati, R. (1999). Network location and learning: The influence of network resources and firm capabilities on alliance formation. Strategic Management Journal, 20(5), 397-420.

Gulati, R., Dialdin, D. A., \& Wang, L. (2002). Organizational Networks. In J. A. C. Baum (Ed.), Blackwell companion to organizations (pp. 288, 309). MA: Blackwell.

Gulati, R., \& Gargiulo, M. (1999). Where do interorganizational networks come from? American Journal of Sociology, 104(5), 1439-1493.

Gulati, R., Nohria, N., \& Zaheer, A. (2000). strategic networks. Strategic Management Journal, 21(3), 199-201. 
Hair, J., Black, W., Babin, B., \& Anderson, R. (2010). Multivariate Data Analysis (7th ed.): New Jersey: Pearson Prentice Hall.

Hair, J. F., Ringle, C. M., \& Sarstedt, M. (2011). PLS-SEM: Indeed a Silver Bullet. The Journal of Marketing Theory and Practice, 19(2), 139 - 152

Hakansson, H. (1989). Corporate Technological Behaviour: Co-operation and Networks. London: Routledge.

Henderson, R. M., \& Clark, K. B. (1990). Architectural Innovation: the Reconfiguration of Existing Product Technologies and the Failure of Established Firms. Administrative Science Quarterly, 35(1), 9-30.

Hippel, E. V. (1988). The Sources of Innovation. New York: Oxford University Press.

Julien, P.-A., Andriambeloson, E., \& Ramangalahy, C. (2004). Networks, weak signals and technological innovations among SMEs in the land-based transportation equipment sector. Entrepreneurship and Regional Development, 16(4), 251-269.

Kaufmann, A., \& Todtling, F. (2001). Science-industry interaction in the process of innovation: the importance of boundary-crossing between systems. Research Policy, 30(5), 791-804.

Koberg, C. S., Detienne, D. R., \& Heppard, K. A. (2003). An empirical test of environmental, organizational, and process factors affecting incremental and radical innovation. Journal of High Technology Management Research, 14(1), 21-45.

Kostopoulos, K. C., Spanos, Y. E., \& Prastacos, G. P. (2002). The resource-based view of the firm and innovation: identification of critical linkages. Paper presented at the European Academy of Management Conference, Stockholm, Sweden.

Laosirihongthong, T., Prajogo, D. I., \& Adebanjo, D. (2014). The relationships between firm's strategy, resources and innovation performance: resources-based view perspective. Production Planning \& Control, 25(15), 1231-1246.

Laumann, E. O., Galaskiewicz, J., \& Marsden, P. V. (1987). Community structure as interorganizational linkages. Annual Review of Sociology, 4(1), 455-484.

Laursen, K., \& Salter, A. (2006). Open for innovation: the role of openness in explaining innovation performance among U.K. manufacturing firms. Strategic Management Journal, 27(2), 131150.

Leischnig, A., Geigenmueller, A., \& Lohmann, S. (2014). On the role of alliance management capability, organizational compatibility, and interaction quality in interorganizational technology transfer. Journal of Business Research, 67(6), 1049-1057.

March, J. G. (1991). Exploration and Exploitation in Organizational Learning. Organization Science, 2(1), 71-87.

Marsden, P. V. (2002). Egocentric and sociocentric measures of network centrality. Social Networks, 24(4), 407-422.

McDermott, C. M., \& O'Connor, G. C. (2002). Managing radical innovation: An overview of emergent strategy issues. The Journal of Product Innovation Management, 19(6), 424-438.

McGrath, R. G. (2001). Exploratory learning, innovative capacity and managerial oversight. Academy of Management Journal, 44(1), 118-131.

Meeus, M. T. H., \& Faber, J. (2006). Interorganizational Relations and Innovation: A Review and a Theoretical Extension. In J. Hage \& M. Meeus (Eds.), Innovation, Science, and Institutional Change. Oxford: Oxford University Press.

Moller, K., Partanen, J., Rajala, R., \& Westerlund, M. (2007). Fostering innovations in the SME context: a network perspective. Paper presented at the 23rd IMP Conference, Manchester UK.

Moser, C. S., \& Kalton, G. (1971). Survey methods in social investigation (2 ${ }^{\text {nd }}$ ed.). Aldershot: Gower.

Mowery, D. C., Oxley, J. E., \& Silverman, B. S. (1996). Strategic alliances and interfirm knowledge transfer. Strategic Management Journal, 17(1), 77-91. 
Nunnally, J. C., \& Bernstein, I. H. (1994). Psychometric theory. New York, NY: McGraw-Hill.

O'Reilly, C. A., \& Tushman, M. L. (2004). The ambidextrous organization. Harvard Business Review, 82(4), 74-81.

Oke, A. (2002). Improving the innovative capability of a service company. Journal of Change Management, 2(3), 272-281.

Oke, A. (2007). Innovation types and innovation management practices in service companies. International Journal of Operations \& Production Management, 27(6), 564-587.

Oke, A., Burke, G., \& Myers, A. (2007). Innovation types and performance in growing UK SMEs. International Journal of Operations \& Production Management, 27(7), 735-753.

Ouimet, M., Landry, R., \& Amara, N. (2004). Network positions and radical innovation: a social network analysis of the Quebec optics/photonics cluster. Paper presented at the DRUID Summer Conference 2004: Industrial Dynamics, Innovation and Development, Denmark.

Pennings, J. M., \& Harianto, F. (1992). Technological Networking and Innovation Implementation. Organization Science, 3(3), 356-382.

Peters, T. J., \& Waterman, R. (1982). In Search of Excellence. Lessons from America's best-run Companies. New York: Harper \& Row.

Pfeffer, J., \& Salancik, G. R. (1987). The external control of organizations: a resource dependence perspective. NewYork: Harper \& Row.

Powell, W. W., Koput, K. W., \& Smith-Doerr, L. (1996). Interorganizational Collaboration and the Locus of Innovation: Networks of Learning in Biotechnology. Administrative Science Quarterly, 41(1), 116-145.

Provan, K. G., Fish, A., \& Sydow, J. (2007). Interorganizational Networks at the Network Level: A Review of the Empirical Literature on Whole Networks. Journal of Management, 33(3), 479-516.

Ragin, C. C. (2008). Redesigning social inquiry: Fuzzy sets and beyond: University of Chicago Press.

Ragin, C. C., Drass, K. A., \& Davey, S. (2006). Fuzzy-Set/Qualitative Comparative Analysis 2.0. Tucson, Arizona Department of Sociology, University of Arizona.

Reichstein, T., \& Salter, A. (2006). Investigating the sources of process innovation among UK manufacturing firms. Industrial and Corporate Change, 15(4), 653-682.

Rihoux, B., \& Lobe, B. (2009). The case for qualitative comparative analysis (QCA): Adding leverage for thick cross-case comparison. London: Sage Publications.

Rodan, S., \& Galunic, C. (2004). More than network structure: How knowledge heterogeneity influences managerial performance and innovativeness. Strategic Management Journal, 25(6), 541-562.

Rowley, T., Behrens, D., \& Krackhardt, D. (2000). Redundant governance structures: An analysis of structural and relational embeddedness in the steel and semiconductor industries. Strategic Management Journal, 21(3), 369-386.

Sammarra, A., \& Biggiero, L. (2008). Heterogeneity and specificity of inter-firm knowledge flows in innovation networks. Journal of Management Studies, 45(4), 200-829.

Simard, C., \& West, J. (2006). Knowledge Networks and the Geographic Locus of Innovation. In H. Chesbrough, W. Vanhaverbeke, \& J. West (Eds.), Open Innovation Researching a New Paradigm. Norfolk: Oxford University Press.

Smith, K. G., Carroll, S. J., \& Ashford, S. J. (1995). Intra-and interorganizational cooperation: Toward a research agenda. Academy of Management Journal, 38(1), 7-23.

Song, X. M., Benedetto, C., \& Zhao, Y. L. (1999). Pioneering advantages in manufacturing and service industries: Empirical evidence from nine countries. Strategic Management Journal, 20(9), 811-835.

Srivastava, M. K. (2007). Friends or Neighbors? The Effects of Inter-firm Networks and Clusters on Technological Innovations in the U.S. Semiconductor Industry. (Doctor of Philosophy), 
Virginia Polytechnic Institute and State University, Blacksburg. Retrieved from http://scholar.lib.vt.edu/theses/available/etd-10102007144411/unrestricted/Dissertation_Manish_Srivastava_ETD.pdf

Stanko, M. A., \& Olleros, X. (2013). Industry growth and the knowledge spillover regime: Does outsourcing harm innovativeness but help profit? Journal of Business Research, 66(10), 2007-2016.

Stuart, T. E. (2000). Interorganizational Alliances and the Performance of Firms: A Study of Growth and Innovation Rates in a High-Technology Industry. Strategic Management Journal, 21(8), 791-811.

Subramaniam, M., \& Youndt, M. A. (2005). The Influence of Intellectual Capital on the Types of Innovation Capabilities. Academy of Management Journal, 48(3), 450-463.

Woodside, A. G. (2013). Moving beyond multiple regression analysis to algorithms: Calling for adoption of a paradigm shift from symmetric to asymmetric thinking in data analysis and crafting theory. Journal of Business Research, 66(4), 463-472.

Zaheer, A., \& Bell, G. G. (2005). Benefiting from network position: Firm capabilities, structural holes, and performance. Strategic Management Journal, 26(9), 809-825. 